\author{
Iván Dániel-Koi Gyula
}

\title{
A Magyar büntetőjog. Kommentár a gyakorlat számára I-III.
}

\section{Commentary on Hungarian Criminal Code for Practitioners Vol. I-III.}

ÖSSZEFOGLALÁS

A Büntetô Törvénykönyvrôl szóló 2012. évi C. törvény hatálybalépését követôen jelent meg Kónya István szerkesztésében a Magyar büntetôjog. Kommentár a gyakorlat számára I-III. címú, 2000 oldalas kommentár. A kommentár gyakorlati jellegét erôsíti a III. kötet, mely teljes egészében a bírói gyakorlatot mutatja be. A recenzió célja a monumentális kommentár szerkezetének, szerzôinek ismertetése, továbbá erényeinek hangsúlyozása.

Kulcsszavak: büntetôjog, joggyakorlat, kommentár, recenzió

\begin{abstract}
SUMmARY
After the entry into force of Act $\mathrm{C}$ of 2012 on the Criminal Code, the Commentary on the Hungarian Criminal Code for Practitioners, vol. I-III were published on 2000 pages, edited by István Kónya. Presenting judicial practice, Volume III adds a practical guide to the commentary. The review describes the structure, introduces the authors, and evaluates the commentary.
\end{abstract}

Keywords: criminal law, commentary, judicial practice, review

Iván DÁnIEL, tanársegéd, Nemzeti Közszolgálati Egyetem, Államtudományi és Közigazgatási Kar, Lőrincz Lajos Közigazgatási Jogi Intézet; doktoranduszhallgató, Nemzeti Közszolgálati Egyetem, Közigazgatás-tudományi Doktori Iskola (Ivan.Daniel@uni-nke.hu), KoI Gyula tudományos munkatárs, Magyar Tudományos Akadémia, Társadalomtudományi Kutatóközpont, Jogtudományi Intézet; tudományos fốmunkatárs, Nemzeti Közszolgálati Egyetem, Államtudományi és Közigazgatási Kar, Lórincz Lajos Közigazgatási Jogi Intézet (Koi.Gyula@uni-nke.hu). 
A közel 2000 oldalas, elsôsorban a gyakorlat számára készült, magyar büntetôjogi tárgyú kommentár nem ismeretlen a joggyakorlattal foglalatoskodók és a jogkeresố közönség számára. A kötet szerzôi ${ }^{1}$ alapvetôen a Kúria bírái közül kerültek ki. A kötet szerkesztő-lektora Kónya István, a Kúria elnökhelyettese. A szerzók többsége aktív vagy nyugalmazott kúriai tanácselnök, illetve egyikük beosztott kúriai bíró, aki a Büntetô Kollégium elvi munkáját elôkészítô csoport állandó tagja. Szükséges megjegyezni, hogy a korábbi 1978. évi IV. törvénnyel hatályba léptetett Btk. vonatkozásában ez a kommentár egészen egy 1995-ben megjelent elôdkiadványig nyúlik vissza (Berkes et al., 1995:883).

2013. július 1-jén lépett hatályba Magyarország negyedik, teljes büntetô törvénykönyve, a 2012. évi C. törvénnyel. A szerzôk a büntetô törvénykönyv következô részeit dolgozták fel:

Akácz József írta a vagyon elleni erôszakos búncselekmények (XXXV. fejezet), a vagyon elleni búncselekmények (XXXVI. fejezet), illetve a szellemi tulajdonjog elleni bûncselekmények (XXXVII. fejezet) részeket (Kónya, 2013, II. 1354-1454.).

Belegi József a szerzôje az egészséget veszélyeztetô bûncselekmények (XVII. fejezet), a környezet és természet elleni bûncselekmények (XXIII. fejezet), a közbiztonság elleni bûncselekmények (XXX. fejezet), nemzetközi kötelezettségen alapuló közbiztonsági célú gazdasági elôírások elleni búncselekmények (XXXI. fejezet), a köznyugalom elleni bûncselekmények (XXXII. fejezet) címú egységeknek (Kónya, 2013, I. 613-647., II. 989-1019., 1192-1277.).

Katona Sándor munkája az elítéléshez fưzôdô hátrányos jogkövetkezmények és a mentesítés (X. fejezet), valamint a közlekedési bûncselekmények (XXII. fejezet) elnevezésú témakörök (Kónya, 2013, I. 323-335., 900-984.).

Kónya István alkotta meg az alapvetố rendelkezések (I. fejezet), a magyar büntetô joghatóság (II. fejezet), a büntetôjogi felelôsség (III. fejezet), a büntethetôséget kizáró vagy korlátozó okok (IV. fejezet), a büntethetôséget megszüntetô okok (V. fejezet), a büntetôjogi felelôsségre vonás egyéb akadályai (VI. fejezet), az élet, a testi épség és az egészség elleni búncselekmények (XV. fejezet), az egészségügyi beavatkozás és kutatás elleni bûncselekmények (XVI. fejezet), az emberi szabadság elleni búncselekmények (XVIII. fejezet), az emberi méltóság és egyes alapvetô jogok elleni búncselekmények (XXI. fejezet), illetőleg a testületi döntéseket magában foglaló kötetet (III. kötet) (Kónya, 2013, I. 1-163., 467-612., 648-678., 822-899., III. 1-662.). A vállalkozás III. kötete foglalja magában a Kúria (korábban Legfelsôbb Bíróság) büntetôjogi és büntetô eljárásjogi tárgyú testületi állásfoglalásait, jogegységi határozatait és büntetô kollégiumi véleményeit.

Márki Zoltán írta az emberiesség elleni búncselekmények (XIII. fejezet), a háborús búncselekmények (XIV. fejezet), a nemi élet szabadsága és a nemi erkölcs elleni búncselekmények (XIX. fejezet), a gyermekek érdekét sértô és a család elleni bûncselekmények (XX. fejezet), az állam elleni búncselekmények (XXIV. fejezet), a minôsített adat és a nemzeti adatvagyon elleni búncselekmények (XXV. fejezet) fejezeteket (Kónya, 2013, I. 399-466., 679-821., II. 1020-1059.).

Mészár Róza kommentálta a büntetések (VII. fejezet), az intézkedések (VIII. fejezet), a büntetés kiszabása (IX. 
fejezet), a fiatalkorúakra vonatkozó rendelkezések (XI. fejezet), az igazságszolgáltatás elleni bûncselekmények (XXVI. fejezet), a korrupciós búncselekmények (XXVII. fejezet), a hivatali búncselekmények (XXVIII. fejezet), a hivatalos személy elleni búncselekmények (XXIX. fejezet), a közigazgatás rendje elleni búncselekmények (XXXIV. fejezet), a záró rész (értelmezô rendelkezések; egyes bûncselekmények értékhatára és szabálysértési alakzata; hatálybalépés; hatályon kívül helyezô rendelkezések; az Európai Unió jogának való megfelelés) részeket (Kónya, 2013, I. 164-322., 336-369., II. 1060-1191., 1314-1353., 1900-1972.).

Molnár Gábor elemezte a pénz- és bélyegforgalom biztonsága elleni búncselekmények (XXXVIII. fejezet), a költségvetést károsító búncselekmények (XXXIX. fejezet), a pénzmosás (XL. fejezet), a gazdálkodás rendjét sértô bû́ncselekmények (XLI. fejezet), a fogyasztók érdekeit és a gazdasági verseny tisztaságát sértô bûncselekmények (XLII. fejezet), a tiltott adatszerzés és az információs rendszer elleni bûncselekmények (XLIII. fejezet) elnevezésú topikákat (Kónya, 2013, II. 1455-1780.).

Soós László vizsgálta a katonákra vonatkozó rendelkezések (XII. fejezet), a honvédelmi kötelezettség elleni búncselekmények (XLIV. fejezet), a katonai búncselekmények (XLV. fejezet) témaköröket (Kónya, 2013, I. 370-398., II. 1781-1899.).

A Btk.-kommentár sajátossága a háromosztatúság. Ez a hármas tagolás a jogtudomány egy klasszikus hagyományát jeleníti meg, amely egyébiránt még arra a hármas felosztásra megy vissza, amely az életvilágot három formára osztotta fel, nevezetesen: személyekre (personae), dolgokra (res), továbbá keresetekre (acti- ones). Ez az elgondolás még Gaius Institutiones címú, nagyjából a Kr. u. II. század táján keletkezett tankönyvében jelent meg elôször, majd I. Iustinianus császár hivatalos tankönyvként és egyúttal törvénykönyvként, Institutiones seu Elementa címmel hagyományozta tovább e felosztást (Földi-Hamza, 1996:5, 5-8. szélszám). Ez a hármas felosztásra való törekvés Werbőczy István Hármaskönyvében is tovább élt (Werbő́czy, 1517:130). A Hármaskönyv, amely 1504 és 1514 között készült Alsópetényben, nyomtatásban elôször 1517-ben jelent meg Bécsben. Az elsố rész tartalmazza a nemesi szokásjogot, a második részben az eljárásjogról olvashatunk, míg a harmadik rész a vármegyei szokásjogot, valamint a polgárokra és a jobbágyokra vonatkozó szokásjogot foglalja magában. Ez a jogtudósi mú a jogi gondolkodást 1848-ig kizárólagosan meghatározta, ezt követốen is egyes részei, fôleg az öröklési jogi kérdésekben, a történeti alkotmány részeként a továbbiakban is hatályukban fenntartattak. A középkor szükségleteinek megfelelően tartalmazott korabeli büntetôjogot is. ${ }^{2}$ Nyilván ebbe a formai elméleti hagyományba illeszkedik bele ez a háromkötetes magyar büntetôjogi kommentár is. Innen vizsgálva a dolgot, megállapíthatjuk, hogy a büntetôjogi törvénykönyvrôl szóló 2012. évi C. törvény kommentálása során, az elsô kötet teljes egészében magában foglalja a kódex általános részét. (Kónya, 2013, I. 1-398.)

A különös rész XIII-XXII. fejezetei is az I. kötetben kaptak helyet. (Kónya, 2013, I. 399-988.)

A II. kötet a XXIII-XLV. fejezeteket, továbbá a záró részt tartalmazza. (Kónya, 2013, II. 989-1972.)

Az I. és a II. kötet sajátossága, hogy a Btk. egészének természetes egységét je- 